\title{
A Study on the Ways to Professional Development of College English Teachers in the Context of Application-Oriented Transformation in Local Colleges and Universities
}

\author{
Xiulan Dai \\ College English Teaching Department \\ Langfang Teachers University \\ Langfang, China
}

\begin{abstract}
With the trend of application-oriented transformation in local colleges and universities, it is a necessity for promote College English teachers' professional development so as to cultivate qualified talents. The paper presents stimulating college-based teaching practices, teaching reflections in the development of further-developing English courses and team-based teacher cooperation as effective ways to promote College English teachers' professional development.
\end{abstract}

Keywords-College English teachers; teachers' professional development; application-oriented transformation; teaching reflection; teacher cooperation

\section{INTRODUCTION}

Teachers are the key factors in College English teaching. National Mid \& Long Term Education Reform and Development Planning Outline does not only promote local colleges and universities develop with application orientation, but also highlight the role of the teachers as national talent development strategy. Teachers are the key to education reform and innovation. The transformation and development of College English teachers is a necessary response to the training of application-oriented talents. The teachers do not only play a crucial role in the process of developing students' application abilities, they are also one of the key factors to the successful transformation of local colleges and universities.

Through the study on the ways to professional development of College English teachers, a teachers' professional development model that fits for the transformation development in local colleges and universities would be explored and that would be helpful in the cultivation of application-oriented talents.

\section{STUDIES ON TEACHERS’ PROFESSIONAL DEVELOPMENT}

Teachers' professional development has attracted more

Sponsored by 2014 English Teaching Reform of Higher Education Program from Hebei Education Department (research name: " $1+2+n$ " college English teacher team building model and practices in a local college; 2014YYJG011) . and more attention of the researchers. Until now, the effective ways to teachers' professional development that have been conformed include pre -service training, teacher learning and assessment, teachers' cooperative teaching, inter-school project and reflection, etc. With the focus of the studies on teachers' professional development has turned to individual teachers, the promotions of teachers' practices and reflections on their own professional development are increasingly paid more attention.

Practice \& reflection teachers' professional development model argued that reflection is the core of teachers' professional development. It is believed that teachers can promote their own professional development through critical analysis and thinking of their own teaching beliefs and practices. Teacher professional development model proposed by Wallace (1991) believed that the combination of practices and reflections promote teachers' professional development. This model emphasizes the necessity and importance of teaching practices and reflections in teachers' professional development. It is believed that teaching practices and reflections are the basis of teachers' professional development. Besides, teachers' professional development is the natural result of teachers' teaching practices and reflections. Through continuous teaching practices and reflections teachers ultimately develop professional qualities and acquire professional development.

Teachers' professional development relies on internal factors as well as external factors. Xu Jinfen et al. (2014), who is one of the prominent Chinese researchers on teachers' professional development, found that the construction of teachers' personal practice knowledge has the characteristics of being practical, reflective, interactive and autonomous. Another famous researcher Zhou Yan (2008) proposed that teachers must have strong awareness of self-development and positive development attitude, can they show concern of their own professional development and achieve knowledge accumulation and skills development. 


\section{College English Teachers' Professional DEVELOPEMNT IN THE DEVELOPMENT OF FURTHER- DEVELOPING ENGLISH COURSES}

With the trends of application-oriented transformation in local colleges and universities, the requirements for the knowledge and ability of College English teachers have increased so as to cultivate application-oriented talents. The professional development of foreign language teachers includes many aspects: first, the updates and expansions of subject-related knowledge; second, the improvement of teaching skills which cope with the changes of teaching objects and teaching materials; finally, but not the least important, the psychological growth in the process of teaching practices, including the increase of professional confidence and the development of positive attitude. Surveys (Wang Shouren \& Wang Haixiao, 2011) have shown that College English teachers in China have heavy workload, commonly 12 class hours a week or more. Compared with sending teachers to attend academic training or have inservice education, colleges and universities themselves can be the main organizers of teachers' professional development. That would be more practical and economical.

Opening up application-oriented further-developing English courses is one of the greatly-promoted tendency for adapting to the application-oriented transformation. As one of the most important factors in teaching, teachers' professional development is an important factor affecting the success and effectiveness of the application-oriented furtherdeveloping English courses. Stimulating college-based teaching practices and reflections in the development of further-developing English courses and team-based activities would conform to teachers' practical needs and colleges actual conditions. In the following part, ways to realize teachers' professional development through college-based teaching practices and reflections would be discussed.

\section{A. Background information}

The university where the author works combines teachers' professional development with teaching reform and course development and has achieved good effects. According to the need analysis of further-developing English courses development finished by the author(Dai Xiulan, 2015), the further-developing English courses offered to the non-English majors can commonly be divided into three types, including application-oriented courses, cultural awareness development courses and language skills development courses. Taking into account the actual needs of the students, application-oriented courses count most. In the author's university, the courses offered include Cambridge Business English, Business English Videowatching, Listening \& Speaking, Advanced Translation, and Speech Performance etc. To guarantee the effectiveness of those courses, different course development teams are organized. The teachers form teams based on previous knowledge structure and personal interests. The course development teams have to complete course teaching plan design, teaching materials preparation, etc. Also, the team members should cooperate with each other in the process of teaching.
College English teachers usually teach EGP (English for General Purposes). In order to undertake the teaching of further-developing English courses, those teachers need to expand their own knowledge first. Concerning knowledge, the teachers for further-developing English courses should have subject-related knowledge, English Linguistics knowledge and language pedagogy knowledge. For example, the teacher qualified for Cambridge Business English teaching must understand the characteristics of business conversation, the genre features of business writing, etc. In addition, the abilities to analyze business terms and businessrelated knowledge are also needed.

\section{B. Development of knowledge system}

In order to be competent for Cambridge Business English teaching, the course development team members do a large amount of reading and learn subject-related textbooks and teaching materials systematically. To increase knowledge reserves for the opening up of the course, Cambridge Business English team makes full use of university's resources, participating in courses given by English major teachers and subject-related courses offered by the School of Economics, such as Foreign Trade Correspondence, International Trade, International Business Negotiation and International Marketing, etc. the teachers write course participation records very carefully and make comments on classroom teaching decision-making, classroom activities and teaching ideologies, etc. Through those activities, the teachers of the course development team have a comprehensive understanding of the knowledge required for the teaching of the course and realize their own multi-levels knowledge development. The fusion of language knowledge with one certain speciality is not only plane combination of subject-related knowledge but should achieve a consistent purpose. The teachers of the Cambridge Business English course development group integrate related knowledge and form their own new knowledge system based on subjectoverlapping. On the basis of the above, the group members formulate a teaching plan which conforms to the characteristics of Non-English majors and related teaching materials. With the above efforts, the teaching effects can be guaranteed.

\section{Development of teaching idelogies}

In the process of teaching, the teachers pay special attention to students' reflection. After each class, the students can give an evaluation of the class from multiple aspects, including whether the knowledge presented have been learnt, whether the teaching methods effective and whether the assignment arrangements are reasonable. Teachers would give students feedback timely. Based on the students' evaluation, the teacher would do their own teaching reflection. If necessary, the teachers would adjust teaching contents or methods to meet the students' actual needs. In the process of teaching practices and reflections, the teachers improve their teaching ideologies. Student-centered teaching ideology is strengthened and put into practices. The teachers do efforts in motivating students' participation in class and their initiative to do extra-curricular autonomous learning. 


\section{Development of open and postive professional development attitude}

In order to guarantee better teaching effects, the members of the course development team would observe each other's classroom teaching, usually twice a semester. All team members participate in one teacher's class and take down class records. Then the teachers would come together to have a discussion about the classroom teaching. The teacher who gives the class presents his teaching goals, teaching methods and teaching effects, etc. After that, the other teachers summarize the problems, analyze the reasons and put forward suggestions. Based on the discussions, all teachers learn more about the teaching. If necessary, the teacher who gives the class may adjust his own teaching and verify its effects.

Through this kind of activities, the teachers develop the awareness to think about the teaching problems positively. Furthermore, their abilities to find, analyze and solve problems are cultivated. In addition, the awareness and ability of cooperation are gradually strengthened. They are more willing to share the problems they find in their teaching practices and reflections as well as their feelings with the other colleagues. The teachers would have an open discussion about those questions and give suggestions to each other. Open and positive profession development attitude which is an important aspect of teachers' professional development is gradually formed.

\section{COLlEge ENGLish TeACHERS' Professional DEVELOPMENT IN TEACHERS COOPERATION}

Western educational researchers generally believe that the roles of teacher cooperation should be emphasized. The teacher cooperation has become one of the important ways to teachers' professional development. Hargreaves and Dean (2000) believed that teachers' cooperation can help to stimulate teachers' willingness to develop, improve their abilities, so as to ensure the sustainability of teachers' professional development. Teacher cooperation activities provide an interactive platform for teachers' practices and reflections. Chinese scholar Zhou Yan (2008) believed that teachers can get encouragement and stimulation in the exchanges and collisions of ideas among colleagues, thus get new development methods and powers.

\section{A. Development of modern educational technology abilities}

In addition to traditional teacher cooperation activities, such as collective class preparation, classroom participation, the College English teaching department where the author works also organizes a variety of teacher cooperation activities, including the mini-lecture competition which aims to promote teachers' master of modern educational technologies used in class teaching, the thesis reading and reporting activities which aims to promote the development of teachers' scientific research abilities.

Mini-lecture is a popular way of teaching which adapts to students learning habits in the new information era. Our department sends a group of teachers in succession to participate in the training of mini- lecture production ideologies and skills. Since 2013, more than 10 teachers, nearly one in three faculty members have participated in such trainings. Each time, the teachers who have participated in the training would share experiences learnt. In addition, in order to promote the development of all teachers, a minilecture competition has been organized and those who won get award certificates and prizes. Through the production of mini-lecture, the teachers have practical experiences of this modern educational technology and their teaching abilities are further developed. Several teachers participate in provincial min-lecture teaching competitions and win good prizes. In addition, the teaching materials the teachers select all from the textbooks the students are using. Those minilectures would be posted on our students' autonomous learning platform so that all students can benefit. The ultimate goal of teachers' professional development is to strengthen teachers' teaching ability, thus promote students' development. The mini-lecture competition helps the unity of teaching practices and teachers' professional development.

\section{B. Development of scietific research abilities}

Improvement of scientific research ability has always important yet difficult for College English teachers. In order to solve this problem, thesis reading is usually recommended. In order to improve the effects of thesis reading, some tips got from the department where the author works are shared here. Firstly, theses selected should be related with teaching practices. When we organize the thesis reading and reporting activity for the first time, our focuses are about the studies on the teaching of the four basic English skills, listening, speaking, reading and writing. Each group found 10 valuable articles published in recent 10 years, wrote a summary and reported to all faculty members. In the second time, the focus we chose is the hottest research fields, including the practical use of mini-lecture in English teaching, the development of Corpus Linguistics, etc. since those topics have practical use for teachers teaching practices, the teachers have strong motivations to learn. Secondly, inviting an expert researcher to do evaluation is recommended. The interactions between the teachers who are just beginning studies in such field and the expert researchers would make the activity more beneficial.

Through thesis reading and reporting activities, teachers develop awareness to find good scientific research topics and their research abilities are improved. Teachers begin to take the initiative to learn new teaching theories, carry out scientific researches based on problems found in teaching practices and reflections. The teachers are active in writing research articles and applying for research programs.

\section{CONCLUSION}

The application-oriented transformation in local colleges and universities is not only an opportunity to deepen college English teaching reforms, but also a challenge for teachers' professional development. College English teachers must face the challenges positively, try efforts to have professional development, thus adapt to the transformation successfully. Based on teachers qualifications and teachers development needs, This paper presents the ways to promote College 
English teachers professional development, including comprehensive development of knowledge system, teaching ideologies, modern educational technologies and scientific research abilities etc. in the development of furtherdeveloping English courses. College-based teaching practices, reflections and teacher cooperation are effective for College English teachers' professional development. The study would be beneficial for other colleges and universities which face similar application-oriented transformation.

\section{REFERENCES}

[1] Hargraves, A and F. Dean "The three dimensions of reform", Educationsl Leadership 7,pp.30-33.

[2] Wallace, J.M. Training Foreign Language Teachers: A Reflective Approach. Cambridge: Cambridge University Press, pp28-29

[3] Dai Xiulan, "Development of further developing english courses in common teachers colleges based on multi-step need analysis", Studies on Higher Education, pp63-64, Sep. 2015.

[4] Wang Shouren and Wang Haixiao, “ Investigation of current college english teaching in China's colleges and univerites and suggestions on the trends of college english teaching reform ", China's Foreign Language Studies, pp4-11, May 2011.

[5] Xu Jinfen, Cheng Xianglian and Qin Kaili "Narrative inquiry of the professional development of excellent college english teachersexploration of the development of teachers' practical knowledge", Foreign Language and Foreign Language Teaching Teaching,pp1519,June 2014

[6] Zhouyan. "Studies on the development modes of China's english teachers". Foreign Language Teaching and Practices, pp4047,March,2008. 